\title{
The Art Form of Wedha's Pop Art Portrait (WPAP)
}

\author{
Angga Kusuma Dawami' ${ }^{1}$, Martinus Dwi Marianto², \\ Suwarno Wisetrotomo ${ }^{3}$ \\ ${ }^{1}$ Doctoral Student, Graduate School of ISI Yogyakarta, Indonesia \\ ${ }^{1}$ Universitas Indraprasta PGRI, Jakarta, Indonesia \\ ${ }^{2,3}$ Indonesia Institute of the Arts Yogyakarta, Indonesia \\ E-mail: ${ }^{1}$ akdawami@gmail.com
}

\begin{abstract}
Wedha's Pop Art Portrait (WPAP) has become one of the most popular visual arts in Indonesia since Wedha Abdul Rasyid decided on this style in 2010. A decade later, WPAP became part of visual arts in Indonesia, used by many millennial designers, sheltered by the chapter community in regions; Jakarta chapter, Jogjakarta chapter, Surabaya chapter, etc. Visual arts based on faces are a strong characteristic of WPAP. Only a few have achieved the WPAP form in accordance with the art form that Wedha first brought up. Economic motives became the biggest influence on the change in orientation from WPAP art to commodity. Therefore, the art form in WPAP tends to follow market trends. This paper tries to define the existing art in WPAP, with the formulation of the problem: what is the art form in WPAP in Indonesia? The formal approach to art is an important part of knowing art in WPAP. Through descriptiveanalytic, an explanation of the art form in WPAP according to the Wedha's experience is presented in this paper. The analysis is using an analysis of interactions between members of the WPAP community in several chapters which already have a "chapter" community. The art form in WPAP has almost the same characteristics as Wedha's work in the early appearance of WPAP. Wedha had a past that grapples with art work; making illustrations, making magazine covers, making comics, and so on. The makers of WPAP in the WPAP community also have an art form in WPAP that is the same in pattern, because it is based on WPAP that was initiated by Wedha at the beginning of its appearance. The art form in WPAP has characteristics in color and line drawing.
\end{abstract}

Keywords: art form, wedha's pop art portrait, community, visual art

\begin{abstract}
Bentuk Seni dari Wedha's Pop Art Portrait (WPAP)
Abstrak

Wedha's Pop Art Portrait (WPAP) menjadi salah satu seni visual yang banyak digemari sejak Wedha Abdul Rasyid memutuskan gaya ini pada tahun 2010. Satu dekade berikutnya, WPAP menjadi bagian dari seni visual di Indonesia, digunakan oleh banyak desainer milenial, dinaungi oleh komunitas chapter yang ada di wilayah-wilayah; chapter Jakarta, chapter Jogjakarta, chapter Surabaya, dll. Seni visual berbasis pada wajah, menjadi ciri khas yang kuat pada WPAP. Hanya sedikit yang mencapai bentuk WPAP yang sesuai dengan bentuk seni yang Wedha munculkan pertama kali. Motif ekonomi menjadi pengaruh terbesar pada perubahan orientasi dari seni WPAP menjadi komoditi. Sehingga bentuk seni dalam WPAP cenderung untuk mengikuti tren pasar. Tulisan ini mencoba untuk mendefinisikan seni yang ada dalam WPAP, dengan rumusan masalah: Bagaimana bentuk seni dalam WPAP menurut komunitasnya di Indonesia?Pendekatan formal seni menjadi bagian penting untuk mengetahui seni dalam WPAP. Melalui diskriptif-analitik, penjelasan tentang bentuk seni dalam WPAP menurut komunitasnya disajikan dalam tulisan ini. Analisis yang digunakan adalah analisis interaksi antar anggota komunitas WPAP di beberapa chapter yang telah memiliki komunitas "chapter". Bentuk seni dalam WPAP memiliki ciri khas yang hampir sama dengan karya Wedha pada awal-awal kemunculan WPAP pertama kali.
\end{abstract}


Wedha memiliki masa lalu yang bergulat dengan pekerjaan seni; membuat ilustrasi, membuat cover majalah, membuat komik, dan lain sebagainya. Pembuat WPAP di komunitas WPAP juga memiliki bentuk seni dalam WPAP yang sama secara pola, karena memang berbasis pada WPAP yang dicetuskan oleh Wedha pada awal kemunculannya. Bentuk seni dalam WPAP memiliki ciri khas dalam warna, tarikan garis, pemilihan pallet, konstruksi wajah.

Kata kunci: bentuk seni, wedha's pop art portrait, komunitas, seni visual

\section{INTRODUCTION}

This paper is a sub-part of a major research which is being carried out in a dissertation research. The approach in this paper is based on the research of the dissertation research plan in the form of a formal approach that emphasizes the form of the artwork, the structure in it, and the visual elements which appear in the artwork. The big topic that was raised was Wedha's Pop Art Portrait.

The existence of modern art institutions - museums, galleries, art books are part of the cultural tradition of art history, related to individual ideas and creativity (Tanner: 12). Wedha's Pop Art Portrait (which is later called using the abbreviation - WPAP), one of the most popular visual arts since Wedha Abdul Rasyid decided to introduce this style in 1990's when he worked in Hai Magazine and become historical in Indonesia visual art. A decade later, WPAP became part of visual arts in Indonesia, used by many millennial designers, were shaded by communities that have chapter titles, where they were located in regions in Indonesia; the Jakarta chapter, the Jogjakarta chapter, the Surabaya chapter, etc. For decades, art history had been concerned with aesthetic issues.

WPAP was not against any kind of art, nor did it react to contemporary art when it existed in its era, but it was the industrial ideology that was firmly held when WPAP appeared. On the way WPAP goes forward, as in Wedha's works it only displays portrait images, it has become a major identity to shape this style into one of the popular mass arts. Starting from Illustration, where illustration is the beginning of Wedha's work in cultivating WPAP to find FMB techniques (techniques before WPAP), these early WPAP works by Wedha first have artistic value in form and meaning.

In the following decade, on WPAP works by Wedha followers, it has a different ideology and development motivation, the art that appears in their work is also different from the art in WPAP by Wedha. In general, the ideas for WPAP which exist in Indonesia, like American Pop Art, which uses famous people to become part of their visual style, are still used as the main identity. The most important thing about WPAP is how WPAP displays portraits at the creation of the first WPAP by Wedha, then by the community it becomes very diverse, and becomes a style outside of the Portrait form. 
The WPAP community in these various chapters are the core of WPAP to be able to develop and continue the style which new digital visual artists are put their love and concern. Wedha's desire, who continues to want to contribute to art in Indonesia, is another part of WPAP's motivation to be thrown to the supporting community. Communities which developing WPAP style have different militancy by Wedha's art forms, especially fine art, which existed in Indonesia in the 2010s, after the WPAP was 'official' by Wedha through in solo exhibition. The WPAP Communities have independent financing, as well as activities carried out by the WPAP Community. It make the WPAP still exist to maintain its style in the wider community and create authority over the WPAP itself. This authority can be owned by individuals or by groups or by a particular institution (Rondhi: 122). The community makes its own artistic authority as a standard which is agreed upon indirectly by its members.

WPAP visual art claimed become art who was born in first time and raised from Indonesia. Wedha's thinking on his discourse as an art that resembles Japanese-manga, WPAP-Indonesia is Wedha's big vision for his idea of becoming a separate style and genre. There are a pride which is brought as part of art life in Indonesia. Visual art based on faces is a strong feature of WPAP. Just only a few have achieved a WPAP form that is compatible with the art form that Wedha first appeared in 1990's.

The economic motive become the biggest influence on the change of orientation from the art of WPAP to commodity oriented, through community authorities, is growing rapidly. Now, the art form in WPAP tends to follow market trends, where many artists have the motivation to sell their work compared to making art works which embody ideas from within the artist. A fundamental question arises, about this WPAP form in its art form origins. This paper tries answer the research question: what is the art form in WPAP in Indonesia?

\section{MATERIALS AND METHOD}

This paper takes data using snowball techniques through virtual, which goes from one chapter to another, and has only explored the three major chapters that still exist today; Solo Chapter, Semarang Chapter, and Jakarta Chapter. Snowball sampling is a useful methodology in exploratory, qualitative and descriptive research, especially in those studies that respondents are few in number or a high degree of trust is required to initiate the contact; hard to reach/hard to involve a population (Baltar and Brunet: 60). The activities carried out are monitoring chapter activities in the virtual area; IG, Facebook, and the Chapter's community social media accounts; then confirm it with an open interview. Online languages are 
embedded in and therefore can prove the 'local knowledge' of visible virtual communities (Mann and Stewart: 207).

The formal approach to art is an important part of knowing art in WPAP. The formalist theory of art asserts that we should focus only on the formal properties of art — the "form" (Noël Carroll: 48). Those formal properties include, for the visual arts, color, shape, and line. Through the descriptive-analytic method, an explanation of the art form in WPAP according to Wedha is presented in this paper. The analysis used is the analysis of interactions between members of the WPAP community in several chapters that already have a "chapter" community.

Due to the active consideration of the members and the construction of the community who are still working on behalf of the community, this research is expected to be able to provide a representation that can contribute to broad knowledge about WPAP itself, and Indonesian visual arts in general. At the big research stage, it is hoped that it can examine all WPAP chapters in Indonesia.

\section{RESULTS}

Wedha likes spatial measurement (stereometry) since Junior High School. Starting from this measurement science, Wedha imagines the human face as a collection of flat (geometric) areas formed by imaginary lines. The early works of the concept of a human face consisting of geometric planes by Wedha were in the form of free strokes and used crayon medium. This is what ultimately makes Wedha, unconsciously, choose to use works with straight lines, rather than curved lines (interview with Wedha Abdul Rasyid, 28 October 2015).

The credo that was brought when the WPAP appeared was to create a strike field, had a hard line that was formed. It will give a strong and solid impression (interview with Wedha Abdul Rasyid, March 8, 2021)

During high school, Wedha attended the LEBAH (Lembaga Budaya Angkatan Hijau), a studio which concentrated in the arts, especially fine arts. After high school, Wedha get study architecture in University of Indonesia, at which time his family was in a bad economic condition (interview with Wedha Abdul Rasyid, 28 October 2015). According Wedha, architecture is a combination of exact science and art. Seeing and demonstrating diagonal lines, technicalities in exact science that initially had to be known to know many things, gradually became less and more dominated by art. Experience with what Wedha likes until the university stage, is still the same and consistent with a straight line; likes straight lines, and outlined planes. Wedha can be seen as someone who really likes lines which also affects the way he triggers the WPAP, by using lots of straight lines, and ultimately forming imaginary lines. (interview with Wedha Abdul Rasyid, 15 April 2016). 
Wedha gave an example when making a Foto Marak Berkotak (FMB) which according to her taste was according to her taste, then when it was published it did not get a "understand" response from the reader. So, there Wedha felt the need to get rid of the work, then Wedha stated that, "people understand what I expect, I am happy. Hopefully you enjoy it in your own way. Because the way to enjoy it is different. But the main thing is who he understands who the character is, ".

There is an inner urge to strengthen the line elements, according to the completeness of a composition, there are lines, there are planes. The underlying intuition is still the same. With the medium of poster color, I applied these strong lines when I painted the face of David Foster, who at that time visited our magazine, and also for Bob Geldof. But then, I felt that the look of the lines didn't blend with the colors. And when it comes to coloring, it feels the appearance of the line is exaggerated. Colors that are already different, when juxtaposed, will automatically form their own dividing line, even though the dividing line is imaginary (Rasyid: 28).

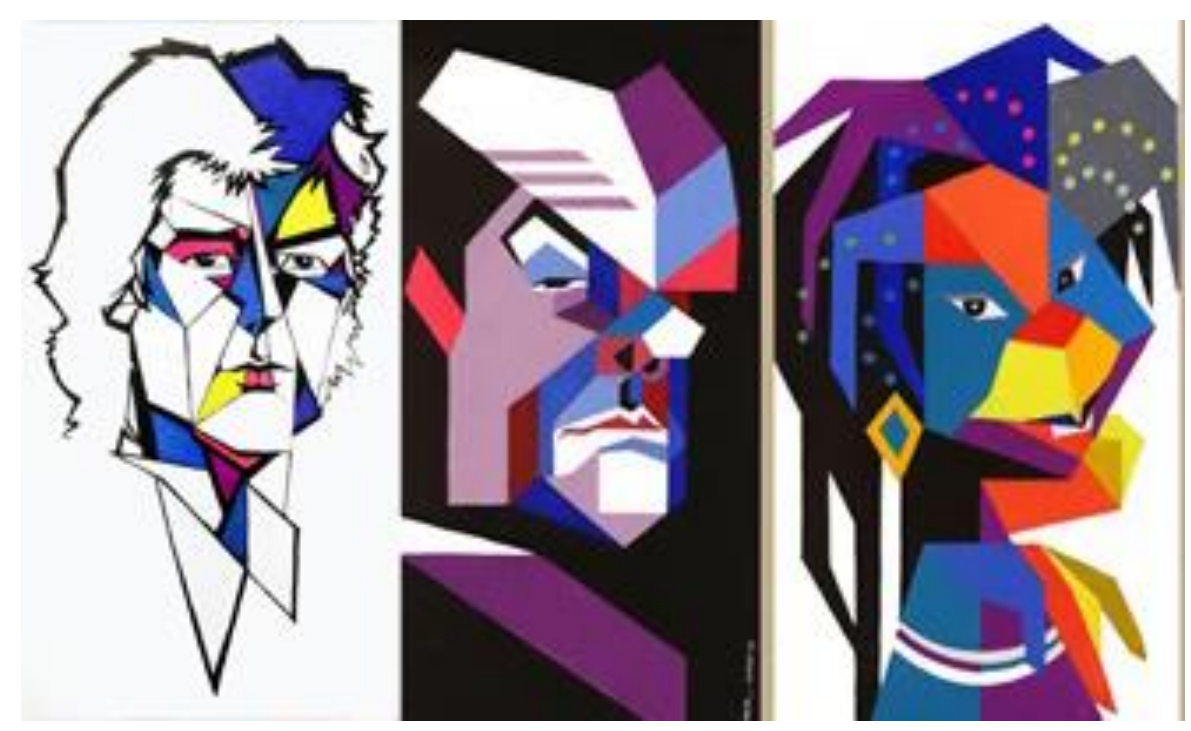

Figure 1. (form left of the Art) Freedy Mercury; Jack Nicholson, Whoopie Golberg. FMB by Wedha Abdul Rasyid

Source: Repro Photo on Wedha \& WPAP (2009:29-31)

In that position, Wedha finally explained the importance of understanding the 'who' figure in a WPAP work, this was also strengthened in the WPAP Semarang community statement, which should follow what Wedha said as clear rules of the WPAP (in the WPAP discussion) WPAP Chapter Solo X WPAP Chapter Semarang (19 July 2020) This should be explored by everyone who studies WPAP as an art like Wedha giving WPAP to the wider community.

In WPAP, the lines that appear are imaginary lines, occur from the effect of colliding colors and have areas of firm lines. The colors used are also in accordance 
with the direction of the incident light. Bright colors for the parts that are exposed to light and dark colors for the parts that form shadows so that it gives a 'life' impression in a portrait image. The difference in color that is different from one another according to Wedha is to create dimensions, so that a Wedha's work on the WPAP considers yellow as the front color (Maarif: 75).



Figure 2. Step to creating WPAP Source: www.wpapcommunity.com accessed on 17 June 2018 17:36

WPAP requires the makers to follow Wedha as the founding father of WPAP. Although in the application, there is WPAP Anomaly, which is a WPAP that does not use a portrait, or human face as its object, and Wedha does allow this as a future WPAP development. The WPAP art form defined by Wedha can be seen from (1) the line, which is influenced by the way the lines are drawn; (2) color selection, will later form the desired facial dimensions.

\section{DISCUSSION}

Wedha tried his best in explaining about WPAP, about what he raised and how the thought process was. A little bit, Wedha's past about the birth of WPAP gave a lot of role to his work when it was created. In the previous chapter, it was discussed how Wedha finally proceeded from Foto Marak Berkotak (FMB) to Wedha's Pop Art Portrait (WPAP). Pleasure towards straight fields, triggers, building design, makes Wedha pay full attention to the origin, WPAP.

WPAP by Wedha, made according to what Wedha wants, techniques, colors and "different shades." The tool used is a computerized technology tool, which is rampant in the 20th century. Applications on canvas, or in any media are possible for Wedha or other WPAP artists.

Wedha's thinking shows that WPAP is indeed different from other styles of art. Gusti Hamdan Firmanta (in an interview 26 June 2019), stated that the WPAP visual style is very different from the cubism visual style or the visual style of Andy Warhol. In WPAP, the lines that appear are imaginary lines, which occur from the 
effect of colliding colors and have a plane of firm lines. The colors used are also in accordance with the direction of the incident light. The color for the parts that are affected by light and dark colors for the parts that form the shadows so that the impression is 'alive' in a portrait image.

The problem of coloring, Wedha (69) said that he had left the grip of human skin color, also with free strokes at the start of FMB. The presentation of works using the popular WPAP painting style follows Wedha's intuition when observing someone's face (usually famous figures in their respective fields, as contained in the characteristics of Pop Art), through the original photos. Wedha tried his best to capture the expressions of the figures faced through several photos to get the right portrait in making FMB's work on the WPAP embryo. In color processing, Wedha does a unique thing in executing his work, namely replacing the color in the dark and light of the photo, with another color that has the same color strength. Suppose that the bright color in the sun is replaced by a light pink color, a slightly darker color is replaced by a purple color.

The forms of WPAP that have been presented in the previous findings subchapter provide an overview of how WPAP has its artistic pattern from Wedha, and has become part of the developing visual arts in Indonesia. The economic impact and strength of the community are things that make WPAP widely known and its development is in great demand by people in Indonesia.

WPAP development at the community level made WPAP art develop, but it did not come out of the idea initiated by Wedha. Wedha's work forms have provided examples of the WPAP art form that should be used by the community in any chapter in Indonesia or in the international community.

Wedha's idea in making political figures and community figures is a representation of Wedha's experience of the figures he makes. Each character displayed by Wedha has its own background in the making, faceting and color selection. This theme was taken by Wedha as a form of expression of his ideas in WPAP to present something that needs to be a reminder for the next generation, for Wedha.

The WPAP at this level has the same quality elements as the WPAP regulations that have been thought out by Wedha. The integrity of the elements of form, composed of lines, colors, textures, planes, and balance. Colors in political themes look dominant among bright colors, such as red, orange, green, purple, and dark colors which are not too dominant. 



Figure 3. WPAP of Community Leaders and Politicians by Wedha Abdul Rasyid (Source: Wedha's Art Document, 2016)

All colors are mixed in the drawing space, forming the portrait of the popular figures in the 2000s and influential people before. The colors used by Wedha in describing figures with political themes have their own characteristics, such as Barack Obama, Georg W. Bush, J. F. Kennedy, Soekarno, Osama bin Laden, and Indira Gandhi. The color choices in the characters are filled in according to the character's character. Even though the color used is not human skin color, 
with the WPAP color rules, the character of each character is clearly visible on the WPAP Wedha.

Soekarno's portrait, with a dominant red and white color to form the impression that Soekarno really came from Indonesia, this color depicts Soekarno's nationalism in fighting for Indonesia. This can be seen from how Soekarno's expression shows his fighting spirit in giving speeches, supported by a red and white background, the symbol of the Republic of Indonesia. Wedha's pride in Soekarno is clearly seen in this WPAP work; this is also reflected in Wedha's vision to grant the WPAP technique as an initiated technique from and for Indonesia. The background area that is formed shows how Soekarno was screaming to encourage those who saw it in his original style.

Portrait of George W. Bush, known as the president who made many wars in the world. Wedha gives dominant red, black, and hot colors to Bush's portrait. This image gives off an impression of anger, dislike, and deserves a red report card. This idea is in line with Bush's past which caused chaos in the world in the early 20th century. The attack on oil-producing countries, made Bush's figure described by Wedha as a cruel, cruel gaze. Not deserving of world attention for his services to hurt many countries, with the dividing line in the middle of his face and the expression on Bush's face that does not smile.

Indira Gandhi's portrait, this portrait is also not very well known by many people. The colors used are bright colors, reflected in his face, such as: yellow, green, blue, and a little brown as a shadow in the image. Prime Minister of Meteri in the land of Hindustan, India. A steel-hearted woman who leads her people to fight without violence, with a determination to what is believed in her struggle. Wedha presents the figure of Gandhi as a warrior with a smile which indicates Wedha's satisfaction with what Gandhi has done to his community.

Portrait of Osama bin Laden, using colorful colors. A positive aura radiates on this WPAP. The predominantly bright colors like a rainbow. Osama is depicted by Wedha with many colors, depicting a calm facial expression but many colors that represent Osama, full of meaning. Osama's character is really shown through his distinctive face with a long beard. Osama's spirit of struggle can be seen clearly in the look on his face how Osama remains calm, even though his enemy, America, continues to be hostile to him and his group through the media.

Barack Obama's portrait, uses the dominant colors orange and brown, with more colors with heavy intensity than light ones. Obama's upward look shows his seriousness in fighting for America. His speech-like style illustrates that Obama deserves to be president of America, who at that time became the first black person to become president of America. Fields like the screams in the comics show that he has a big vision. The eyes that look forward also support this. Obama was described 
by Wedha when he was going to the American presidential election in 2008. It is obvious how Wedha shows his concern for changes in America.

The unity of the five Portraits drawn using the WPAP technique by Wedha, all of them, are supported by the expressions of each face depicted. The impression that arises is anger, hatred, enthusiasm, sincerity, reflected in the political theme made by Wedha using WPAP. Wedha wants to communicate with the audience about how exactly, each character is depicted, there are many messages to remember as the next generation.

Wedha have a love for lines without curves, and it can be seen from the works of the WPAP that were sparked at the Wedha exhibition at Bentara Budaya Jakarta. This is also supported by (Rasyid: 31-40) in his book discussing the structure of the WPAP. WPAP is referred to as WPAP, if:

1. Field, a field in the WPAP by the anatomical proportions of the portrait created.

2. Imaginary lines, lines that are formed not from the outline of the formed plane, but from the collision of two or more colors. The lines present are straight lines, where everyone can see the firmness in WPAP, simple, but can capture the character.

3. Colors, the colors used in the WPAP are colors that match the color concept determined by Wedha, where the light color is the area that is more famous for light than the dark color is the area that becomes a shadow in the dark a portrait.

Table 1. Use of Color and Draw a Line by Wedha

Source: Personal Documentation, 2017

\begin{tabular}{l|l|l}
\hline $\begin{array}{l}\text { Wedha's Artwork in } \\
\text { Community Leaders and } \\
\text { Politicians }\end{array}$ & Cofinition the form \\
\hline & TS T AT AG G GS & $\begin{array}{l}\text { The colors in this } \\
\text { Politicians-themed work } \\
\text { tend to be varied in order } \\
\text { to get impressions in } \\
\text { accordance with the } \\
\text { character of a politician } \\
\text { who is strong, firm, and } \\
\text { has character. }\end{array}$ \\
\hline
\end{tabular}


As a repertoire of what's happening in the world. It can be seen from the repertoire of figures that the community described by Wedha as part of their own experiences, draws a line firmly, with colors that match the character's character, character and idealism. There is a line drawing and color selection section in the WPAP as the most important part of the WPAP construction itself. So, it can be drawn that core are; First, from drawing facial lines that will give a different impression from one another; Second, from choosing a color that matches the character that will give dimension in the WPAP work.

\section{CONCLUSION}

There are not many people who understand WPAP as an important part of life. The WPAP art form can be seen from the line and color draws, both of which are benchmarks for the current developing WPAP art. The form of facets continues to evolve from every thought that follows WPAP, making various lines of diversity that make WPAP more diverse and creating new clusters in the WPAP itself in its development.

Wedha Abdul Rasyid has provided knowledge about art styles that various groups in Indonesia can use. To this day, WPAP is used for artists and designers interested in constructing the WPAP thought itself. In addition, there are experiences about the characters who have to participate in the WPAP made.

The art form in WPAP has characteristics that should be the same as Wedha's work in the early days of WPAP's appearance. Wedha has past wrestling with artwork; make illustrations, make magazine covers, make comics, etc. WPAP makers in the WPAP community also have an art form in WPAP, which is the same pattern because it is based on the WPAP, which Wedha coined at the beginning of its appearance. The art form in WPAP is characterized by color and line drawing and an understanding of the portrait that will be used as an imitated object.

As a science, WPAP also requires wisdom in its thinking. Pop Art has become an art genre that does carry rebellious values in society in general, but this does not happen to WPAP. The rebellion that occurred at WPAP was in the technical way of making it. At first, it was Wedha's difficulty in making realistic images according to human skin tones, but it became various colors, like Pop Art colors. The concepts raised also provide a complete picture of people's lives, to remember something popular in their day, in general. 


\section{REFERENCES}

Baltar, Fabiola, and Ignasi Brunet. (2012). "Social Research 2.0: Virtual Snowball Sampling Method Using Facebook." Internet Research, vol. 22, no. 1, Jan. 2012, pp. 57-74, doi:10.1108/10662241211199960.

Maarif, Yosi Samsul. (2017). "Kreativitas Wedha' s Pop Art Portrait." PANTUN, no. 52,2017 , pp. $68-77$, https://jurnal.isbi.ac.id/index.php/pantun/article/view/753.

Mann, Contributors Chris, and Fiona Stewart. (2000). "Internet Communication and Qualitative Research Power Issues in Internet Research Power Issues in Internet Research." Internet Communication and Qualitative Research, 2000, p. 203.

Noël Carroll. (1999). Philosophy of Art: A Contemporary Introduction.

Rasyid, Wedha Abdul. (2011). Wedha \& WPAP, Pop Art Asli Indonesia. 1st ed. Elex Media Komputindo.

Rondhi, Mohammad. (2014). "Fungsi Seni Bagi Kehidupan Manusia: Kajian Teoretik." Jurnal Imajinasi, vol. VIII, no. 2, 2014, pp. 115-28, https://journal.unnes.ac.id/nju/index.php/imajinasi/article/view/8872.

Tanner, Jeremy. (2004). "Sociology of Art: A Reader." Sociology of Art: A Reader, 2004, doi:10.4324/9780203633649.

\section{Informants / Resources}

Wedha Abdul Rasyid, 74, (2021) Founder Wedha's Pop Art Portrait. Kembangan, Jakarta Barat, DKI Jakarta.

Gusti Hamdan Firmanta, 33 (2019), Sociopreuner and WPAP enthusiast. Surabaya, Jawa Timur. 